\title{
AN UPDATED CHECKLIST OF MOSSES OF XINJIANG, CHINA ${ }^{1}$ НОВЫЙ СПИСОК МХОВ СИНЬЦЗЯНЯ, КИТАЙ ${ }^{1}$ BENITO C. TAN ${ }^{2}$, JIAN-CHENG ZHAO ${ }^{3}$ AND REN-LIANG HU ${ }^{4}$
}

An updated checklist of Xinjiang mosses based on past publications and new collections made in 1993 showed a total of 130 genera, 339 species and 8 infraspecific taxa. Twelve species and two varieties are reported here as new to China. They are Amblyodon dealbatus, Bryum schleicheri var. latifolium, Conardia compacta, Cynodontium schistii, Dicranella schreberiana, Orthotrichum cupulatum, O. hallii, O. pallens, O. speciosum var. elegans, Physcomitrium pyriforme, Pottia bryoides, P. heimii, Sphagnum warnstorfii and Tortella nitida. Amblyodon and Conardia are two new moss generic records for China.

Резюме

Новый список листостебельных мхов Синьцзян-Уйгурского автономного округа (северо-западный Китай) основан на последних публикациях и сборах авторов в 1993 году. Список включает 339 видов и 8 внутривидовых таксонов из 130 родов. Двенадцать видов и две разновидности приводятся впервые для Китая: Amblyodon dealbatus, Bryum schleicheri var. latifolium, Conardia compacta, Cynodontium schistii, Dicranella schreberiana, Orthotrichum cupulatum, O. hallii, O. pallens, O. speciosum var. elegans, Physcomitrium pyriforme, Pottia bryoides, P. heimii, Sphagnum warnstorfii и Tortella nitida. Два рода, Amblyodon и Conardia, найдены в Китае впервые.

\section{INTRODUCTION}

The study area, Xinjiang Uygur Autonomous Region, is the largest province of China, representing roughly $1 / 6$ of the national territory. It is situated in the northwestern corner of the country $\left(34^{\circ} 15^{\prime}-49^{\circ} 11^{\prime} \mathrm{N}, 73^{\circ} 21^{\prime}-96^{\circ} 25^{\prime} \mathrm{E}\right)$ with a total land area of 1657549 square kilometers (Fig. 1). Although a large part of the province consists of desert and semi-desert grassland, large tracts of boreal forests of Picea, Abies and Lar$i x$ cover much of the northern slopes of mountains at high elevations, especially in places where there is a good supply of water from glacier melt. From north to south three mountain ranges, Altai, Tianshan (Tian-Schan) and Karakorum/ Kunlun, divide the province into a north and south basin, namely the Junggar Basin and the Tarim Basin (see Fig. 1). The topography of the province is very complex and diverse. A broad altitudinal range exists between Qogir Peak $(8611 \mathrm{~m})$, the second highest peak in the world, and Aydingkol Lake $(-154 \mathrm{~m})$, the lowest part of China. Because of the "blocking effect" of the
Himalayan Range, moist air currents from the Indian Ocean fail to reach Xinjiang, resulting in the vast expanse of arid terrain. Hydrologically, there is a progressive increase of precipitation from south to north, with the Altai region receiving the highest annual precipitation. Occupying the heart of the Eurasian land mass, Xinjiang province has a unique flora representing a mixture of circum-boreal, Irano-Turanian and Eastern Asiatic taxa. Bryologically, because of the transportation barrier in the past, the province is one of the lesser investigated regions of China.

The history of Xinjiang bryology was reviewed by Zhao (1993b) who reported that the two earliest publications of Xinjiang mosses were by Tchen (1936) and de la Varde (1937). However, systematic collection of Xinjiang mosses by professional bryologists did not commence until the second author started the investigation in 1985. In one of his recent publications, Zhao (1993b) counted a total of 97 genera and 242 species of mosses for the eastern section of Tian-

1 - Contributions to the Bryoflora of China no. 11.

2 - Farlow Herbarium, Harvard University, 22 Divinity Avenue, Cambridge, Massachusetts 02138, U.S.A.

3 - Department of Biology, Xinjiang University, Urumqi 830046, Xinjiang Province, China.

4 - Department of Biology, East China University, Shanghai 200062, China. 


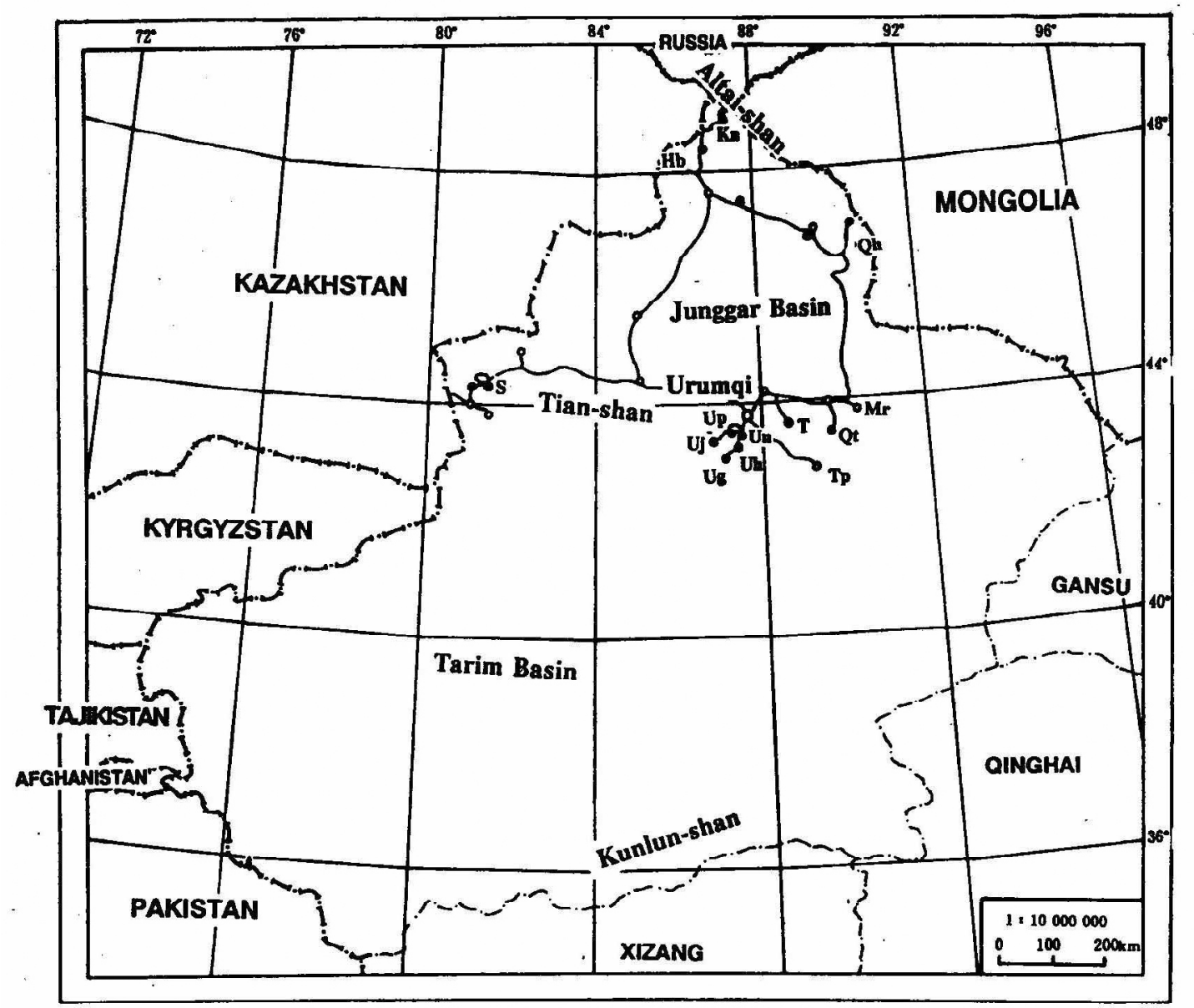

Map 1. Boundary of Xinjiang Province, China, showing the collection localities (solid dots) in abbreviation and other geographical information. See text for the full collection locality information.

shan. He also calculated that $58.63 \%$ of these taxa belong to Holarctic elements, $9.24 \%$ are taxa of the temperate Asiatian range, and about $8.84 \%$ are Eurasian taxa.

Supported by the National Geographic Society, we undertook in July-August of 1993 a one month bryological expedition to 15 localities in Tianshan and Altai (see Map 1) and collected a total of 1,000 numbers. It is on this basis that we report here 57 species (marked with a $*$ ) and 21 genera (marked with $* *$ ) as new to the Xinjiang moss flora. Of these, 12 species and two varieties are new records for China (marked with ***). They are Amblyodon dealbatus, Bryum schleicheri var. latifolium, Conardia compacta, Cynodontium schistii, Dicranella schreberiana, Orthotrichum cupulatum, O. hallii, O. pallens, O. speciosum var. elegans, Physcomitrium pyri- forme, Pottia bryoides, P. heimii, Sphagnum warnstorfii and Tortella nitida. Amblyodon and Conardia are two new generic records for China. Since little is known about the moss flora of this remote part of the world, we decided to publish our preliminary determinations and include in the list other taxa of Xinjiang mosses reported in publications. The final tally is 130 genera, 339 species and 8 infraspecific taxa.

In the list of Xinjiang mosses presented below, all names of accepted taxa are arranged alphabetically. Nomenclatures and authority names follow Ignatov \& Afonina (1992). Synonyms are listed inside a [ ] after the accepted binomial. Our 1993 collections are followed by a locality information. However, names of reported species not collected by us are indicated by the source literature. Where appropriate, the 
species range in China is discussed. New records of Xinjiang and Chinese mosses are reported with the locality information and collector/collection number(s). Lastly, correction of past erroneous reports is included in the section of excluded and doubtful taxa. As is, a complete set of voucher specimens are deposited at the herbarium of Xinjiang University, with a second and a third, incomplete set kept at FH and HSNU respectively.

Based on this updated checklist, the following generalizations can be stated to characterize the Xinjiang moss flora:

1) It is predominantly a boreal and arcticalpine flora;

2) Pottiaceae, Grimmiaceae, Encalyptaceae and Orthotrichaceae are richly represented at low elevations;

3) High species diversity occurs in semi-open, mesic to hydric, forested habitat at mid-montane elevations;

4) Although the province has limited limestone and other calcareous formations, small patches of calciphilous taxa are frequently encounted;

5) The flora has few Sino-Japanese and SinoHimalayan taxa;

6) No endemic taxa, although the adjacent Russian Altai region has a few endemics that may eventually be found in this province;

7) No tropical or subtropical taxa;

8) Polytrichaceae, Sphagnaceae and Andreaeaceae, for reasons not yet understood, are poorly represented. To date, Andreaea still has no Xinjiang record although its presence in the surrounding countries and provinces is well documented.

\section{COLLECTION LOCALITIES}

The abbreviation of the collection localitites (see Fig. 1) are as follows:

$\mathrm{Br}$ - Burqin Co., roadside alkaline pond 60 $\mathrm{km}$ east of Burqin town proper, elev. ca. $500 \mathrm{~m}$;

Fy - Fuyun Co., Fuyun Copper Mine site, elev. ca. $500 \mathrm{~m}$;

$\mathrm{H}$ - Huocheng Co., Xin'ertai road section, vicinity of Guo-zi-gou (Fruit Valley), elev. 1140$1500 \mathrm{~m}$;

$\mathrm{Hb}$ - Habahe Co., $40 \mathrm{~km}$ north of Habahe town, roadside rocky slopes near Baihapa army station, elev. 1200-1600 m;
K - Kanash (Hanash) Lake Nature Reserve in Altai Range, elev. 1300-1350 m;

Qh - Qinghe Co., Qinghe Forest Preserve, elev. 1300-1700 m;

Qt - Qitai Co., Pan-jie-gou (Half Valley) Hei-lau-pa (plain), elev. 2000-2130 m;

S - Salimu (Sayram) Lake vicinity, elev. 1900-2100 m;

$\mathrm{T}$ - Tian-chi (Heavenly Lake), lakeshore Picea forests, elev. 1940-2000 m;

Tp - Turfan Co., Grape Valley village;

Ug - No. 1 Glacier in Tienshan range, elev. 3600-3900 m;

Uh - $10 \mathrm{~km}$ south of Huoxia town in Nanshan, Tianshan range, elev. 2300-2500 m;

$\mathrm{Uj}$ - Ju-hua-tai (Chrysanthemum Plateau) in Nanshan, Tianshan range, $70 \mathrm{~km} \mathrm{SW}$ of Uqumqi City, elev. 2310-2400 m;

Un - Nan-tai-zi picnic ground in Nanshan, Tianshan range, $52 \mathrm{~km} \mathrm{~S}$ of Urumqi City, elev. ca. $1700 \mathrm{~m}$;

Up - Bai-yang-gou (Poplar Valley) in Nanshan, Tianshan range, $55 \mathrm{~km} \mathrm{SW}$ of Urumqi City, elev. ca. $1900 \mathrm{~m}$.

\section{AN UPDATED LIST OF XINJIANG MOSSES}

Abietinella abietina (Hedw.) Fleisch. - Hb, $\mathrm{K}, \mathrm{Qt}, \mathrm{S}, \mathrm{T}, \mathrm{Up}$.

A. HISTRICOSA (Mitt.) Broth. [Zhao 1993a]

**Aloina RigIDA (Hedw.) Limpr. - Hb, Ug, Un, Tan 93-897, 93-972, 93-1013, new generic and species records. This seems like a common xeric moss in China, colonizing bare, sandy and silty grounds. Its thick leaf with broadly involute margins covering numerous photosynthetic filaments on the adaxial surface of the costa is peculiar. Outside China, A. rigida has a nearly cosmopolitan range.

***AMBLyOdON DEALBATUS (Hedw.) Bruch et Schimp. in B.S.G. - S, Qt, Uj, Tan 93-867, 93-949, 93-1020. Both the genus and the species are new to China. The curved, asymmetrical capsule with a neck, typically of the family Meesiaceae, plus the lax, thinwalled, leaf cells, identify the genus. Xinjiang is well within the reported range of this species across the Northern Hemisphere.

AMblystegium SERPENS (Hedw.) Schimp. in B.S.G. - H, Hb, K, Qt, S, T.

**AMPHIDIUM LAPPONICUM (Hedw.) Schimp. Ug, Tan 93-964, new generic and species records. A widespread Holarctic taxon, this species is also known from Heilongjiang and Shaanxi Provinces.

ANOECTANGIUM THOMSONII Mitt. [Zhao 1993a]

ANOMOBRYUM FILIFORME (Griff.) Jaeg. [Anonymous 1978; Chen 1963] 
A. FILIFORME var. CONCINNATUM (Spruce) Loeske [Zhang 1978]

ANOMODON MINOR (Hedw.) Fuernr. [Gao 1977]

A. RUGEliI (C. Muell.) Keissl. [Gao 1977]

Aulacomnium androgynum (Hedw.) Schwaegr. - Qh.

A. Palustre (Hedw.) Schwaegr. - K.

A. TURGIDUM (Wahlenb.) Schwaegr. [Anonymous 1978; Zhao et al. 1989]

BARBULA LONGICOSTATA Li [Zhao 1993b]

B. UNGUICULATA Hedw. [Zhao 1993a]

BARTRAMIA POMIFORMIS Hedw. - Uj.

B. ITHYPHYLLA Brid. [Zhao et al. 1989]

BRACHYTHECIUM ALBICANS (Hedw.) Schimp. in B.S.G. - S.

B. BUCHANANII (Hook.) Jaeg. - S.

B. CAMPEStRE (C. Muell.) Schimp. in B.S.G. [Zhao 1993a]

B. Collinum (C. Muell.) Schimp. in B.S.G. [Chen 1978]

B. Garovaglioides C. Muell. [Zhao 1993a]

B. GLAREOSUM (Spruce) Schimp. in B.S.G. [Zhao 1993b]

B. KUROISHICUM Besch. [Zhao 1993a]

B. Plumosum (Hedw.) Schimp. in B.S.G. [Zhao 1993a]

B. Plumosum var. MimMAYAe Card. [Qian 1987]

B. POPUlEuM (Hedw.) Schimp. in B.S.G. [Anonymous 1978]

B. PROCUMBENS (Mitt.) Jaeg. [Zhao 1993b]

B. REFLEXUM (Starke) Schimp. in B.S.G. [Zhao 1993a]

B. RHYNCHOSTEGIELlOIDES Card. [Zhao 1993a]

B. RIVULARE Schimp. in B.S.G. [de la Varde 1937]

B. Rutabulum (Hedw.) Schimp. in B.S.G. [Zhao 1993b]

B. SAlebrosum (Web. et Mohr) Schimp. in B.S.G. - H.

B. STARKEI (Brid.) Schimp. in B.S.G. [Zhao 1993a]

B. Velutinum (Hedw.) Schimp. in B.S.G. [Zhao 1993b]

B. WiChurae (Broth.) Par. [Qian 1987]

BRyHnia NOVAE-ANGLiaE (Sull. et Lesq.) Grout [syn. B. sublaevifolia Broth. et Par. ex Card.] [Zhao 1993a]

BRYOERYTHROPHYLLUM INAEQUALIFOLIUM

(Tayl.) Zander [syn. Barbula tenii Herz.] [Zhao 1993b]

B. Recurvirostrum (Hedw.) Chen - Qh, Qt,

$\mathrm{S}, \mathrm{T}, \mathrm{Uj}, \mathrm{Un}, \mathrm{Up}$.

BRYUM ALPINUM Huds. ex With. [Zhao 1993a]

B. ANGUSTIRETE Kindb. in Macoun - Uh.

B. ARGENTEUM Hedw. - H, S.

B. ARCTICUM (R. Br.) Bruch et Schimp. in B.S.G.

[Zhao 1993a]

B. ATROVIRENS Vill. ex Brid. [Anonymous 1985]
B. BICOLOR Dicks. [Anonymous 1985]

B. CAESPITICIUM Hedw. [Anonymous 1978; Zhao 1993a]

B. CALOPHYLlUM R. Br. [Anonymous 1978; Zhao 1993a]

B. CApillare Hedw. - H, S.

B. Cellulare Hook. in Schwaegr. - S.

B. CYCLOPHYLlum (Schwaegr.) Bruch et Schimp. in B.S.G. - K.

B. KNOWLTONII Barnes [Zhao 1993a]

B. LONCHOCAULON C. Muell. [syn. B. cirrhatum Hoppe et Hornsch. ex Hornsch.] [Zhao 1993a]

B. NEODAMENSE Itzigs. in C. Muell. [Zhao 1993a]

B. PALlENS (Brid.) Sw. in Roehl. - Ug, Up.

B. PALLESCENS Schleich. ex Schwaegr. - Qt.

B. PSEUdotriquetrum (Hedw.) Gaertn. et al. - Qt.

B. PURPURASCENS (R. Br.) Bruch et Schimp. in B.S.G. [Anonymous 1985]

B. RECURVUlum Mitt. [Zhao 1993a]

B. RUTILANS Brid. - Up.

B. SAUTERI Bruch et Schimp. in B.S.G. [Zhao 1993b]

***B. SCHLEICHERI Schwaegr. var. LATIFOLIUM (Schwaegr.) Kindb. [syn. B. tianshanicum Zhao et al., in scheda] - Qh, QT, T. This is a subcosmopolitan moss in wet habitat, easily recognized by its stout, tumid, scarcely branched stems of watery green color. The leaves are large, broadly ovate, concave, broadly acute to obtuse and with a strong border. Although Nyholm (1954-1969) dismissed the species as a hybrid between $B$. turbinatum and B. pseudotriquetrum, we think that the species, especially var. latifolium, is very distinctive in the field.

B. TURBINATUM (Hedw.) Turn. [Anonymous 1978; de la Varde 1937]

B. TRUNCORUM (Brid.) Brid. [Zhao 1993a]

B. Uliginosum (Brid.) Bruch et Schimp. in B.S.G. [syn. B. cernuum (Hedw.) Bruch et Schimp. in B.S.G.] [Zhao 1993a]

CALliergon giganteum (Schimp.) Kindb. - Qh, Qt. CAMPTHOTHECIUM AURICUlatUM (Jaeg.) Broth. [Zhao 1993a]

C. Lutescens (Hedw.) Schimp. in B.S.G. [Zhao 1993a]

*Campylium hispidulum (Brid.) Mitt. - Un, Tan 93-1009, new to the province.

*C. POlygamum (B.S.G.) C. Jens. [syn. Campyliadelphus polygamus (B.S.G.) Kanda] - S, Tan 93946, new to the province. This Campylium species has both uni- and bicostate leaves.

C. PROTENSUM (Brid.) Kindb. [Zhao 1993a]

C. Stellatum (Hedw.) C. Jens. - Ug.

CAMPYlopus fleXuOSus (Hedw.) Brid. [Zhao et al. 1989]

C. FRAGILIS (Brid.) Bruch et Schimp. in B.S.G. [Zhao 1993a] 
C. SCHIMPERI Milde [syn. C. subulatus Schimp. in Rabenh. var. schimperi (Milde) Husn.] [Zhao et al. 1989]

Ceratodon purpureus (Hedw.) Brid. - K, H, Qh, S.

Chenia leptophylla (C. Muell.) Zander [syn. Pottia splachnobryoides C. Muell.] [Zhao 1993b]

CINCLIDIUM ARCTICUM Bruch et Schimp. in B.S.G. [X.-J. Li \& Zhang 1979]

C. STYGiUm Sw. in Schrad. [Gao 1977]

CIRRIPHYLLUM CIRROSUM (Schwaegr.) Grout -

H, T, Uh, Up.

C. PILIFERUM (Hedw.) Grout [Zhao 1993]

Climacium Dendroides (Hedw.) Web. et Mohr - K, Qh, Qt, Uj.

C. JAPONICUM Lindb. [Zhao et al. 1989]

***CONARdia COMPACTA (C. Muell.) Robins. [syn. Rhynchostegiella compacta (C. Muell.) Loeske] - K, Tan 93-901, new to China. The discovery of this minute, mat-forming, Holarctic species strengthens the boreal affinity of the Xinjiang moss flora. Although the species is distinctive in having a strong, single costa and a serrulate basal leaf margin with recurved teeth, its generic placement for years has been in controversy. Here we accept a separate genus for this unique species. The Xinjiang plants bear abundance of gemmae on its leaf apices.

CRATONEURon Filicinum (Hedw.) Spruce - Qt, $\mathrm{Uj}$. 1992]

CROSSIDIUM CHLORONOTUS (Brid.) Limpr. [Zhao

Ctenidium molluscum (Hedw.) Mitt. [Gao 1977]

***CYNodontium schistil (Web. et Mohr) Lindb. [syn. Cnestrum schistii (Web. et Mohr) Hag.] - Hb, Tan 93-931, new to China. The genus is also a new record for the province. Among the dicranaceous genera, Cynodontium is distinctive in having papillose leaf cells, undifferentiated alar regions, and a markedly striate capsule when dry, with or without struma. Thus far, only two species of Cynodontium are reported from China (Redfearn 1993). Among its congeners, C. schistii is smallest in plant size. It is a boreo-montane species which grows usually in rock crevices.

**CYRTOMNIUM HYMENOPHYLLOIDES (Hueb.) Nyh. ex T. Kop. [syn. Mnium hymenophylloides Hueb.] - Up, Tan 93-997, new generic and species records. A common subalpine moss in the northern hemisphere, this species is recognized by its entire, roundly ovate leaves arranged in two complanate ranks. Prior to our collection, C. hymenophylloides has only one Chinese record from Gansu Province dated 1930 (Koponen 1981). Our specimens were collected from a $\log$ with thick humic soil cover near a waterfall. Crum \& Anderson (1981) has published a very good illustration for this species.
Desmatodon latifolius (Hedw.) Brid. [Zhao 1993a]

*D. LAURERI (Schultz) Bruch et Schimp. in B.S.G. - Ug, Tan 93-969. The differentiated leaf margins, papillose leaf cells and the narrowly ellipsoid capsules should identify this species easily from other congeners in the province.

D. RAUCOPAPILlOSUM Li [Zhao 1993a, b]

D. SYSTYLIUS Schimp. - Qt, Ug, Uj.

Dicranella heteromalla (Hedw.) Schimp. [Anonymous 1985]

***D. SCHREBERIANA (Hedw.) Hilp. ex Crum et Anderson - T, Tan 93-854. Although the collection here appears to be the first for China, this Holarctic species may have been reported in local florulas and provincial checklists under various names such as $D$. palustris sensu lato and D. divaricata (Mitt.) Jaeg.

*D. VARIA (Hedw.) Schimp. - H, Zhao 93187.

DicRanodontiUm DENUdATUM (Brid.) Britt. ex Williams - K.

Dicranoweisia CirRata (Hedw.) Lindb. in Milde [Anonymous 1985; Zhao 1993b]

D. CRISPULA (Hedw.) Lindb. - S.

DICRANUM DELAVAYI Besch. [de la Varde 1937]

D. ELONGATUM Schleich. ex Schwaegr. [Anonymous 1978]

D. FRAGILIFOLIUM Lindb. - Qt

D. GROENLANDICUM Brid. [Anonymous 1985]

D. MUEHLENBECKII Bruch et Schimp. in B.S.G. $-\mathrm{K}$.

D. NIPPONENSE Besch. [Zhao et al. 1989]

D. SCOPARIUM Hedw. - K

D. SPURIUM Hedw. [Anonymous 1978; Gao 1977]

D. UNDULATUM Schrad. ex Brid. [Gao 1977]

DidYMODON ASPERIfOliUs (Mitt.) Crum et al. [syn. Barbula asperifolia Mitt.] [Zhao 1993a]

D. CONSTRICTUS (Mitt.) K. Saito [syn. Barbula constricta Mitt.] -H, Ug.

D. FALlaX (Hedw.) Zander [syn. Barbula fallax Hedw.] [Zhao 1993a]

D. GIGANTEUS (Funck) Jur. [syn. Barbula gigantea Funck] [Zhao 1993a]

D. ICMADOPhiLus (Schimp. ex C. Muell.) K. Saito [Zhao 1993b]

D. NIGRESCENS (Mitt.) K. Saito [syn. Barbula nigrescens Mitt.; B. subrivicola Chen] $-\mathrm{H}, \mathrm{S}, \mathrm{Ug}$.

D. PEROBTUSUS Broth. [syn. Barbula perobtusa (Broth.) Chen] [Zhao 1993a]

D. Rigidicaulis (C. Muell.) Saito [syn. Barbula reflexa (Brid.) Brid.] - Uh.

D. RIGIDULUS Hedw. [syn. Barbula rigidula (Hedw.) Mild.] - H.

D. RIGIDULUS var. DITRICHOIDES (Broth.) Zander [syn. Barbula ditrichoides Broth.] - $\mathrm{H}$.

D. RIVICOLA (Broth.) Zander in T. Kop. et al. [syn. Barbula rivicola Broth.] [Zhao 1993a]

D. Rufidulus (C. Muell.) Broth. [syn. Barbula 
rufidula C. Muell.] [Zhao 1993a]

D. TOPHACEUS (Brid.) Lisa [syn. Barbula tophacea (Brid.) Mitt.] - H.

D. VINEALIS (Brid.) Zander [syn. Barbula subcontorta Broth.; B. vinealis Brid.] [Zhao 1993a]

DistichiUm CAPILlaCEUM (Hedw.) Bruch et Schimp. in B.S.G. - H, Qt, S, Uh, Ug.

D. HAGENII Ryan ex Philib. - Ug.

D. InClinatum (Hedw.) Bruch et Schimp. in B.S.G. - S.

DITRICHUM CRISPATISSIMUM (C. Muell.) Par. [syn. D. flexicaule sensu Chinese authors] [de la Varde 1937; Tchen 1936]

D. DIFFICILE (Duby) Fleisch. - S.

Drepanocladus ADUNCUS (Hedw.) Warnst. Qt.

D. SENDTNERI (Schimp. ex C. Muell.) Warnst. [Anonymous 1978]

**DRUMMONDIA THOMSONII Mitt. - T, Tan 93853, new generic and species records. In Orthotrichaceae, Drummondia and Zygodon have similar cucullate calyptrae. The two genera also possess rather similar leaf outline and areolation, but the leaf cells of Drummondia are smooth and that of Zygodon are papillose. At present, Zygodon has not been found in Xinjiang. Its occurrence in the province can be expected. According to Vitt (1972), D. thomsonii differs from D. turkestanica Broth. ex C. Muell. in having a less gradually slender leaf apex. The Xinjiang specimen, which was collected from the trunk of a Populus, has leaf apices of both types. It is likely that these two geographically juxtaposit species may prove conspecific when the variations of their leaf morphologies are better known. From the widespread $D$. sinensis C. Muell., D. thomsonii differs in being a smaller plant and having a more acuminate leaf apex, in addition to having a whitish capsule. Mature capsules of $D$. sinensis are brownish in color. D. thomsonii is also known from Xizang and the Khasmir region.

ENCALYPTA alPina Sm. - Qt, Uj.

E. CILIATA Hedw. - Qt.

E. RHAPTOCARPA Schwaegr. - Qt.

E. Spathulata C. Muell. - Uh, Un.

E. VULGARIS Hedw. - H.

ENTOdon COMPRESSUs (Hedw.) C. Muell. [Zhao et al. 1989; Zhao 1990]

E. CONCINnUs (De Not.) Par. - S.

*E. LURIDUS (Griff.) Jaeg. - T, Zhao 2792b.

E. oBtusAtus Broth. [Zhao 1993a]

E. SEDUCTRIX (Hedw.) C. Muell. [Zhao 1993a]

*Eurhynchium praelongum (Hedw.) Schimp.

in B.S.G. [syn. Kindbergia praelonga (Hedw.) Ochyra] - S, Zhao 93102.

E. PUlChELlum (Hedw.) Jenn. [Zhao 1993a]

E. SAVATIERI Schimp. ex Besch. [Zhao 1993a]

EUROHYPNUM LEPTOTHALlum (C. Muell.) Ando [syn. Homomallium leptothallum (C. Muell.) Nog.] [Zhao 1993b]

**FABRONIA CILIARIS (Brid.) Brid. - Hb, Tan 93-937, specimen mixed with Neckera pennata, new generic and species record for the province. The same species has been reported from the neighboring Inner Mongolia Province of China and the Kazakhstan Republic.

*FISSIDENS BRYOIDES Hedw. - H, S, T, Uh, Uj, Un, Up, Tan 93-852, 93-939, 93-985, 93-988, 93-1006, 93-1007, 93-1028, a new provincial species records. Up until 1992, there were no Xinjiang records of Fissidens (Z.-H. Li 1992). In 1993 Zhao made the first generic report (as $F$. grandifrons) for the province. We are pleased to report two species of Fissidens from this vastly arid part of China.

*F. PERDECURRENS Besch. - T, Zhao 2610; Turfan, Grape Valley, Tan 93-961, a new provincial species record. Locally, F. perdecurrens prefers dripping wet rocks in deeply shaded places. Its local distribution is peculiar in having a coastal distribution with disjunctive inland populations in Guizhou and Xinjiang Provinces.

FONTINALIS ANTIPYRETICA Hedw. var. ANTIPYRETICA - Qh.

F. ANTIPYRETICA var. GRACILIS (Lindb.) Schimp. [syn. F. gothica Card. et H. Arnell] [Zhao 1993a]

F. HYPNOIDES Hartm. [Chen \& al. 1958]

F. SQUAMOSA Hedw. [Chen \& al. 1958]

FUNARIA HYGROMETRICA Hedw. - K, Ug, Up.

F. Microstoma Bruch ex Schimp. [Zhao 1993b]

*F. MUeHLenbergiI Turn. - Qh, Tan 93-873, 931031 , new to the province. In Xinjiang, this species is relatively common in shaded sites underneath rocks. The concave, broadly ovate to obovate leaves with hairpoints, coupled with the erect, though slightly asymmetrical, capsule, will separate this from $F$. hygrometrica. Reportedly a calciphile, $F$. muehlenbergii has been found in all northern provinces of China.

GRIMMIA AFFINIS Hoppe et Hornsch. ex Hornsch. $-\mathrm{K}$.

G. ANODON Bruch et Schimp. in B.S.G. - Qh, T, Uh, Un.

G. APICULATA Hornsch. [Zhao 1993a]

G. ATRATA Miel. ex Hornsch. [Zhao 1993b]

G. DONNIANA Sm. - Ug.

G. ELATIOR Bruch ex Bals. et De Not. [Zhao 1993a]

G. ELONGATA Kaulf. in Sturm [Zhao 1993a]

G. LAEVIGATA (Brid.) Brid. [Zhao 1993a]

G. MACROTHECA Mitt. [Zhao 1993b]

G. MONTANA Bruch et Schimp. in B.S.G. - H, $\mathrm{Ug}$.

G. obTUSifolia Gao et Cao - Ug.

G. OVAlis (Hedw.) Lindb. [syn. G. commutata

Hueb.] [Zhao 1993a]

*G. PILIfERA P. Beauv. - Ug, Tan 93-1190A. 
G. Pulvinata (Hedw.) Sm. - H, Qh.

G. SEssitana De Not. - Ug.

*G. TERgestina Tomm. ex B.S.G. - Uh, Tan 93980, 93-1220, a new record for Xinjiang. G. tergisti$n a$ has been reported from many interior provinces of China (Redfearn 1993), although Cao \& Vitt (1986) showed it only from Gansu and Jiangsu Provinces.

G. UNICOLOR Hook. in Grev. - Ug.

GYMNOSTOMUM AERUGINOSUM Sm. [Zhao 1993b]

G. CALCAREum Nees et Hornsch. in Nees et al. [Zhao 1993b]

**Hamatocaulis lapponicus (Norrl.) Hedenaes [syn. Drepanocladus lapponicus (Norrl.) Z. Smirn.] - K.

**H. VERnicosus (Mitt.) Hedenaes [syn. Drepanocladus vernicosus (Mitt.) Warnst.] [Anonymous 1978] $1993 \mathrm{a}$

HAPlohymenium triste (Ces.) Kindb. [Zhao

Hedwigia Ciliata (Hedw.) P. Beauv. [syn. $H$. albicans Lindb.] - B, K.

Helodium BLANDOWII (Web. et Mohr.) Warnst. [syn. H. lanatum (Brid.) Broth.] [Anonymous 1978]

Homomallium CONNEXUM (Card.) Broth. [Zhao 1993a]

HYGROAMBLESTEGIUM NOTEROPHILUM (Sull. et

Lesq.) Warnst. - Qh, Uj.

H. TENAX (Hedw.) Jenn. [Bai 1987] 1963]

HYGROHYPNUM FONTINALIOIDES Chen [Chen

H. LURIDUM (Hedw.) Jenn. [syn. H. palustre Loeske] - Up; Balikun County, Zhao 1377.

H. LURIDUM var. EHLEI (Arn.) Wijk et Marg. [Zhao 1993a]

H. MOLlE (Hedw.) Loeske [syn. H. dilatatum (Wils.) Loeske] [Zhao 1993a]

H. MONTANUM (Lindb.) Broth. [Zhao 1993a]

Hylocomium Splendens (Hedw.) Schimp. in B.S.G. [syn. H. proliferum (Brid.) Lindb., nom. illeg.]

HYMENOSTYLIUM RECURVIROSTRUM (Hedw.)

Dix. [de la Varde 1937]

HYPNUM CALLICHROUM Brid. [Zhao 1993a]

H. CUPRESSIFORME Hedw. - T.

H. HAMUlOSUM Schimp. in B.S.G. - S.

H. PALlescens (Hedw.) P. Beauv. [Zhao 1993a]

H. PLUMAEFORME Wils. [Tchen 1936; Zhao 1993a]

H. Procerrimum Mol. [syn. Pseudostereodon procerrimus (Mol.) Fleisch.] [de la Varde 1937]

H. Revolutum (Mitt.) Lindb. - S.

INDUSIELla THIANSHANICA Broth. et C. Muell. in Broth. [Zhao 1992]

** ISOPTERYGIOPSIS PUlChella (Hedw.) Iwats. [syn. Isopterygium pulchellum (Hedw.) Jaeg.] - Uh, Up, Tan 93-983, 93-986, 93-1000b, new generic and species records. This seems like a widespread ground species in the province. The papillose rhizoids arising from inside leaf axils, the narrowly lanceolate and entire leaves, and the nearly erect, cylindric capsules are good telling characters (Nyholm 1954-1969; Crum \& Anderson 1981). Although a widespread species, $I$. pulchella has only one other Hebei collection reported by C.-Y. Yang in 1934. Its presence in other northern provinces should be looked for.

JAFFUELIOBRYUM WRIGTII (Sull.) Thŭr. [Zhao 1992]

LEPTOBRYUM PYRIFORME (Hedw.) Wils. - Qh, Qt, S.

*LePtodictyum RIPARIUM (Hedw.) Warnst. $11 \mathrm{~km}$ SE of Urumqi near Chai-wo-pu Lake, Tan 931165. This widespread species prefers wet, swampy and eutrophic habitats.

LEPTOPTERIGYNANDRUM STRICTICAULE Broth. [Zhao 1993a]

Lescuraea incurvata (Hedw.) Lawt. [syn. Pseudoleskea incurvata (Hedw.) Loeske] - K, Un.

*L. SAXicola (Schimp.) Milde - T, Tan 93-840, Zhao 3012 , new to the province. For a circumpolar and mountain species, it is surprising to note that the only other Chinese record is from the offshore island of Taiwan. The often reported species in northern China, L. incurvata (Hedw.) Lawt., differs from the present species primarily in having short, rectangular to irregularly shaped median and basal leaf cells. In L. saxicola, the median and basal leaf cells are oblong to elongate.

LiMPRICHTIA REVOlVEns (Sw.) Loeske [syn. Drepanocladus revolvens (Sw.) Warnst.] - S.

LINDBERGIA SINENSIS (C. Muell.) Broth. [Zhao 1993a]

Meesia Uliginosa Hedw. [syn. M. trichodes Spruce] [de la Varde 1937; Zhao 1993b]

MNIUM AMBIGUUM H. Muell. [syn. M. magnirete (Lindb. et Arn.) Kindb.] [Zhao 1993b]

M. LAEVINERVE Card. - H, S, T.

M. LYCOPODIOIDES Schwaegr. [syn. M. longispinum X.-J. Li et Zhang; M. pseudolycopodioides C. Muell. et Kindb. in Macoun] - Qt.

M. MARginatum (With.) Brid. ex P. Beauv. $\mathrm{H}, \mathrm{Up}$.

M. SPINOSUM (Voit) Schwaegr. [Zhao 1993b]

M. STEllare Hedw. - S, T.

M. THOMSONII Schimp. [syn. M. orthorrhynchi$u m$ Brid.] - H.

Myurella Julacea (Schwaegr.) Schimp. in B.S.G. - Uj, Up.

M. SIBIRICA (C. Muell.) Reim. [syn. M. gracilis Lindb.] - Up.

M. TENERRIMA (Brid.) Lindb. [Anonymous 1978]

**NeCKera Pennata Hedw. - Hb, Tan 93-933, 93-934, new generic and species records. The family Neckeraceae is a new addition to the provincial flora. Perhaps because of the arid climate, this species grows 
locally as small patches of populations in shaded sites underneath boulders or protected rock cliffs. N. pennata is a common species in China. $\mathrm{Uj}$.

ONCOPHORUS VIRENS (Hedw.) Brid. - Qt, Uh,

O. WAhlenbergil Brid. - K, Qt, Uh.

OREOWEISIA TORQUESCENS (Brid.) Wijk et Marg. [syn. O. serrulata (Funck) De Not.] [Chen 1963]

ORTHOTHECIUM CHRYSEUM (Schwaegr. ex Schultes) Schimp. in B.S.G. [syn. Entodon chryseum (Schwaegr.) B.S.G. in Zhao (1993a), orthographical error] [de la Varde 1937]

O. RUFESCENS (Brid.) Schimp. in B.S.G. [Zhao 1993b]

ORThotrichum AFFine Schrad. ex Brid. [Zhao 1993b]

O. ANOMALUm Hedw. - Uh, T.

***O. CUPULATUM Brid. - Qh, Tan 93-1105, new to China. It is a welcome to find this nearly cosmopolitan in the Xinjiang part of China. The local population grows on river bank near the road to Qinghe Forest Reserve. The same species has been reported from Middle Asia and Altai Mountains in former USSR. Its presence in other northern provinces of China can be expected. The small plant with strongly furrowed, emergent capsule showing 16 erect, standing exostome teeth are good diagnostic features. More importantly, the stomates are immersed.

***O. HALLII Sull. et Lesq. in Sull. - Qh, Tan 93-1070, 93-1078, 93-1083, new species record for China. The detailed information of the range disjunction of this species in western North America and China will be reported separately by Lewinsky-Haapasaari \& Tan (1994).

O. OBtUSIFOLIUM Brid. - Qh, T, Up. The species seems to prefer the trunk of Populus in all the reported localities.

***O. PALLENS Bruch ex Brid. - Qh, Tan 931086 , specimen mixed with $O$. obtusifolium, new to China. This is another widespread Holarctic species that has no previous Chinese record before our Xinjiang collection. The Chinese plants were found growing on trunks of Populus inside a riverine, deciduous, broad-leaved forest. Elsewhere, it is known from Kashmir, Kazakhstan, Russian Altai and other parts of Sibiria.

O. RUPESTRE Schleich. ex Schwaegr. - K, T.

O. SPECIOSUM Nees in Sturm - K, Qt, T, Ug.

***O. SPECIOSUM var. ELEGANS (Schwaegr. ex Hook. et Grev.) Warnst. - T, Tan 93-831, 93-842, new to China.

*O. SORDIDUM Sull. et Lesq. in Aust. - H, K, Qt, T, Tan 93-1042, 93-1068, 93-1121b, 93-1158. This and $O$. speciosum are the two most common Orthotricha encountered during this expedition. Often, the two grow together with individual plants intermixed. Both species can be recognised from other members of the genus by their exserted capsule with eight reflexed exostome teeth and superficial stomates on the capsule. However, $O$. sordidum has a distinctly ribbed capsule at maturity when dry, whereas $O$. speciosum has a smooth capsule.

O. STRIATUM Hedw. [Zhao 1993a]

O. URNIGERUM Myr. [Zhao 1993a]

OXYsTegus CUSPIDATUS (Dozy et Molk.) Chen [Zhao 1933a]

O. TEnUIROstris (Hook. et Tayl.) A. J. E. Smith [Zhao 1993a]

Palamocladium euchloron (C. Muell.) Wijk et Marg. [Zhao 1993a]

Paludella squarrosa (Hedw.) Brid. [Anonymous 1978]

Palustriella commutata (Brid.) Ochyra [syn. Cratoneuron commutatum (Brid.) G. Roth] - Uj.

** Phascum Cuspidatum Hedw. - Qh, Tan 93879 , new generic and species records. This is an ephemeral, pioneering moss in many arid habitats such as fallow fields and roadside banks. It has only one previous Chinese report which is from the Inner Mongolia Province (Bai 1987).

Philonotis fontana (Hedw.) Brid. [de la Varde 1937]

P. NITIDA Mitt. [Zhao 1993b]

PHYSCOMITRIUM EURYSTOMUM Sendtn. [Zhao 1993a]

***P. PYRIFORME (Hedw.) Hampe - Qh, Tan 93-871, new to China. That this Holarctic species has no previous Chinese report is a surprise. It is possible that specimens of $P$. pyriforme have been confused with P. eurystomum Sendtn., which is a smaller plant. In $P$. pyriforme, the leaf costa reaches only the apex or disappears below it, while in P. eurystomum, it is shortly excurrent. P. pyriforme grows commonly on wet clayey soil.

**PLAGIOBRYUM DEMISSUM (Hook.) Lindb. Ug, Uj, Tan 93-965, 93-1021, new generic and species records. According to Nyholm (1954-1969), the much inclined, pyriform capsule is a good diagnostic character for the species. Other Chinese records are from Shaanxi and Yunnan.

Plagiomnium Cuspidatum (Hedw.) T. Kop. [syn. Mnium cuspidatum Hedw.] [Zhao 1993a]

P. ELLIPTICUM (Brid.) T. Kop. [syn. Mnium rugicum Laur.; Mnium affine var. rugicum (Laur.) Bruch et Schimp. in B.S.G.; Mnium latilimbatum X.-J. Li et Zhang] - K, Qt, Uh.

P. INTEGRUM (Bosch et Sande Lac.) T. Kop. [Zhao 1993a]

P. MEDIUM (B.S.G.) T. Kop. - K.

P. Rostratum (Schrad.) T. Kop. - H.

P. TEZUKAE (Sak.) T. Kop. [Zhao 1993a]

P. Vesicatum (Besch.) T. Kop. - K, Qh, S.

Plagiopus oederiana ( $\mathrm{Sw}$.) Crum et Anderson - Uh, Up. 
**Plagiothecium Laetum Schimp. in B.S.G. K, Uj, Up, Tan 93-987, 93-1000a, 93-1029, new generic and species records. The addition of this Holarctic moss genus and species to the local flora is expected. Its previous Chinese records are from Jilin and Xizang provinces.

PlatyGYRIUM REPENS (Brid.) Schimp. in B.S.G. - $\mathrm{Hb}$. 989]

PleURIDIUM ACUMINATUM Lindb. [Zhao et al.

**PleUROZIOPSIS RUTHENICA (Weinm.) Kindb. ex Britt. - Qh, Tan 93-888, new generic and species records for the province. The moss family, Pleuroziopsidaceae, is a new addition to the province. Sterile materials of $P$. ruthenica can be difficult to segregate from the equally dendroid plants of Climacium. Under the circumstances, the presence of tiny stem lamellae in Pleuroziopsis, best seen in cross section of stem, is a reliable character (Ireland 1968). In addition, stem and branch leaves of $P$. ruthenica have mostly round to broadly obtuse apices whereas branch leaves of Climacium have obtuse-acute apices. In Xinjiang, $P$. ruthenica grows in a flooded, forested site by a river. Other Chinese collections from Heilongjiang, Jilin, Liaoning, Shaanxi, Sichuan and Xizang are reportedly from mesic forest sites.

Pleurozium Schreberi (Brid.) Mitt. - K, T.

Pogonatum Dentatum (Brid.) Brid. [syn. $P$. capillare Michx.] [Zhao 1993a]

P. Perichaetiale (Mont.) Jaeg. [Zhao et al. 1989]

P. URnigerum (Hedw.) P. Beauv. [Zhao 1993a]

POHLIA CRUDA (Hedw.) Lindb. - K.

P. Elongata Hedw. ssp. Elongata [syn. $P$. acuminata Hoppe et Hornsch. ex Hornsch.] - Ug, $\mathrm{Uj}, \mathrm{T}$.

P. ElONGATA ssp. POLYMORPHA (Hoppe et Hornsch. ex Hornsch.) Nyh. [syn. P. polymorpha Hoppe et Hornsch. ex Hornsch.] [Zhao 1993b]

P. FleXUOSA Hook. [syn. P. gracillima (Card.) Ihs.] - Qh.

P. NUTANS (Hedw.) Lindb. [Anonymous 1978; Zhao 1993a]

P. SAPROPHILA (C. Muell.) Broth. [Zhao 1993b]

POlYTRICHASTRUM ALPINUM (Hedw.) G. L. Smith [syn. Pogonatum alpinum (Hedw.) Roehl] Qt, Ug, Uj, Up.

P. Longisetum (Brid.) G. L. Smith [syn. Polytrichum gracile Dicks. in Menz.] [Zhao et al. 1989]

P. OHIOEnse (Ren. et Card.) G. L. Smith [syn. Polytrichum decipiens Limpr.] [Zhao et al. 1989]

Polytrichum COMmune Hedw. [Anonymous, 1978; Zhao et al. 1989]

P. JUNIPERINUM Hedw. - K.

P. PILIFERUM Hedw. [Anonymous 1978; Zhao et al. 1989]

P. STRICTUM Brid. [syn. P. alpestre Hoppe; $P$. juniperinum var. affine (Funck) Brid.] [Zhao 1990; Zhao et al. 1989]

***PotTIA BRYOIDES (Dicks.) Mitt. - H, Tan 93-957, new to China. The large, emergent, ovoidoblong and cleistocarpus capsule is very characteristic for the species.

***P. HEIMII (Hedw.) Furnr. - S, Tan 93-948, new to China. In northern Europe, this is reportedly a seashore species rarely found inland (Nyholm 19541969). In western North America, it was reported growing on alkaline soil (Lawton 1971). The Xinjiang population came from the wet, seepy shore of Salimu Lake. Nyholm (1954-1969) recognized the arctic form of this variable species as var. obtusifolia (R. Br.) Hag. which she characterized as having shorter and more broadly lanceolate leaves than those of the type. The Xinjiang specimen fits well this variety.

**PSEUdOCALLIERGON LYCOPODIOIDES (Brid.) Hede-naes [syn. Drepanocladus lycopodioides (Brid.) Warnst.] - Ug.

**P. TURGESCENS (T. Jens.) Loeske [syn. Calliergon turgescens (T. Jens.) Kindb.; Scorpidium turgescens (T. Jens.) Loeske] [Anonymous 1978]

PSEUdOLESKEELla CATENUlata (Brid. ex Schrad.) Kindb. - Ug.

P. NERVOSA (Brid.) Nyh. [syn. Leskeella nervosa (Brid.) Loeske] $-\mathrm{T}$.

P. TECTORUM (Funck ex Brid.) Kindb. in Broth. [syn. Leskeella tectorum (Funck ex Brid.) Hag.] $\mathrm{Br}, \mathrm{H}, \mathrm{Qh}, \mathrm{Qt}, \mathrm{S}, \mathrm{Un}$. One of our Xinjiang collections (Tan 93-894) has specimens with strongly prorate leaf cells on the dorsal side of lamina similar to that seen in P. papillosa (Lindb.) Kindb. [syn. Heterocladium papillosum (Lindb.) Lindb.]. Nonetheless, its longly acuminate leaf apex is like that of $P$. tectorum. In a recent regional monograph, Wilson \& Norris (1989) defined broadly the species concept of $P$. tectorum and included in it all North American and Greenland specimens with papillose or prorate leaf cells which were identified by Steere (1975) and Lewinsky (1974) as "P. papillosa". We think that a good case of parallel evolution exists here between $P$. catenulata and $P$. tectorum, that each species has developed a papillose form within its range. We interpret the Scandinavian P. papillosa as the papillose form of $P$. catenulata, and our Xinjiang and North American collections of so-called "P. papillosa" as the papillose representatives of $P$. tectorum. The latter can be called P. tectorum subsp. cyrtophylla (Kindb.) Lewinsky, although a varietal rank is probably more appropriate for this papillose morph.

PSeudosymblepharis ANgustata (Mitt.) Hilp. [syn. P. papillosula (Card. et Thér.) Broth.] [Zhao 1993a]

*Pterygoneurum Kozlovil Lazar. - Hb, Tan 
93-1032. The adaxially lamellated leaf costa with its long apical awn is unique for the genus. According to McIntosh (1989), the present species resembles $P$. subsessile in having an immersed capsule, but is readily distinguished from the latter by its cleistocarpous capsule. The same author reported that $P$. kozlovii has been considered by many to be of hybrid origin. Our Xinjiang collection which bears several capsules with aborted spores seems to support this hybrid contention. P. kozlovii has a widely disjunctive distribution. Previously it was known only from the Europe (Czechoslovakia and Ukraine), but recently it was found in British Columbia in Western Canada (McIntosh 1989), Mongolia (Abramova \& Zaegmaed, 1989) and now in China.

P. Ovatum (Hedw.) Dix. - Hb, Qh. Although Chen (1963) had long predicted the presence of this widespread moss in China, its discovery was only recently reported from Inner Mongolia (Bai \& Gao 1993) and Xinjiang (Zhao 1993c). Without fruiting bodies, it is difficult to distinguish $P$. ovatum from $P$. subsessile. The taxonomic characters used to separate the two species such as the plant habit, length of leaf awns, and leaf margin are variable and unreliable. This is evident by a comparison of the prepared illustrations of these two species in Crum \& Anderson (1981) and in Abramova \& Abramov (1983).

*P. SUBSESsile (Brid.) Jur. - K, Qh, Tan 93$881,93-915$ pp, a new species record. The most reliable feature of this species is its immersed capsules which are subhemispheric. In $P$. ovatum, the capsules are oblong-ovate and exserted. The other Chinese locality of $P$. subsessile is Inner Mongolia (Bai \& Gao 1993).

*Pterigynandrum filiforme Hedw. - K, Zhu et Zhao 93739.

Ptilium CRISTA-CAStrensis (Hedw.) De Not. $\mathrm{K}$.

**Pylaisiella falcata (Schimp. in B.S.G.) Ando - K, T, Tan 93-902, 93-914, 93-926, 93-927, Zhao 4226, new provincial record for the genus and species. In Xinjiang, this seems to be a common trunk epiphyte inside Abies-Larix forest. It is recognized by its erect, cylindric capsule with well developed exostome and endostome that are free from each other like that seen in Pylaisiella polyantha. Unlike $P$. polyantha, the gametophyte here is larger in every aspect and possesses a different branching habit. To some extent, the gametophyte of $P$. falcata approximates Hondaella in branching pattern, leaf orientation and alar organization, but differs from the latter genus in having smooth and concave leaves (plicate leaf in Hondaella). Leaves of P. falcata are erect to secund, loosely appressed, ovate-lanceolate; lamina with a long, constricted upper portion and short, double costa. Iwatsuki (pers. comm. 1994) first suggested that the specimens might be $P$. falcata. One of the collections was subsequently confirmed by Ando (pers. comm. 1994). In his early publication, Ando (1978) remarked that the species is large and unusual in habit for the genus. Pylaisiella falcata is an example of East Asia-Latin American disjunctive distribution. In China, it is known from Sichuan, Yunnan and Xizang.

**P. POlyantha (Hedw.) Grout [syn. Pylaisia polyantha (Hedw.) Schimp.] - Hb, K, Tan 93-898, 93-908, 93-927b, new generic and species records. The distinction between this species and $P$. selwynii (Kindb.) Crum et al. can be difficult, especially if only one taxon is present at a site. We find that the usually employed discriminating character, i.e., the degree of adherence between the outer peristome teeth and inner peristome segments (see Crum \& Anderson 1981; Nyholm, 1954-1969), is rather difficult to observe in sporophytic specimens of both species. Instead, we rely on the smaller plant size and the presence of more leaf alar cells in P. selwynii as distinguishable features from $P$. polyantha.

**RHIZOMNIUM PSEUDOPUNCTATUM (Bruch et Schimp.) T. Kop. [syn. Mnium pseudopunctatum Bruch et Schimp.] - Uh, Tan 93-984, new generic and species records. In a recent publication, Koponen \& Afonina (1992) show the distribution of this widespread boreal species in Central Siberia north of Xinjiang Province. Other species of Rhizomnium with similar pattern of distribution are $R$. punctatum and $R$. magnifolium. Predictably, these two species will also be found in Xinjiang. R. pseudopunctatum is not listed in the revised list of mniaceous taxa in China studied by Koponen \& Lou (1982). It has an earlier report from Jilin Province (Gao 1977).

**Rhodobryum Roseum (Hedw.) Limpr. - Hb, Zhu 93263, new generic and species records for Xinjiang.

RHYNCHOSTEGIELLA CURVISETA (Brid.) Limpr. [Chen 1978]

R. LEPTONEURA Dix. et Thér. [Zhao 1993b]

RHYNCHOSTEGIUM INCLINATUM (Mitt.) Jaeg. [syn. R. plumosum Thér.] [Zhao 1993a]

R. Murale (Hedw.) Schimp. in B.S.G. - H. RHYTIDIADELPHUS TRIQUETRUS (Hedw.) Warnst. $-\mathrm{K}$.

Rhytidium RUgosum (Hedw.) Kindb. - K.

**SAELANIA GLAUCESCENS (Hedw.) Broth. - Hb, Tan 93-932, new generic and species records. A widespread boreal and subalpine species, S. glaucescens is easily recognized by its powdery, bluish gray coloration. However, care should be taken not to confuse it with the equally bluish plants of Pohlia cruda. In China, $S$. glaucescens is also known from Heilongjiang, Jilin and Shaanxi provinces, and the neighboring Kazakh Republic. A report of it from the subtropical Mt. Jiulong in Zhejiang Province at about $800 \mathrm{~m}$ elevation (Hong \& Hu 1984) needs confirmation. 
SAKURAIA CONCHOPHYLla (Card.) Nog. [syn. Entodon conchophyllus Card.] [Zhao 1993a]

SANIONIA UNCINATA (Hedw.) Loeske [syn. Drepanocladus uncinatus (Hedw.) Warnst.; D. uncinatus f. longicuspis Z. Smirn.] - H, K, Qt, Uh.

SCHISTIDIUM APOCARPUM (Hedw, Bruch et Schimp. in B.S.G. - K.

S. CHENII (Lin) Cao et al. [Cao et al. 1992]

S. Liliputanum (C. Muell.) Deguchi - H, Ug.

S. Rivulare (Brid.) Podp. - Up.

S. STRICTUM (Turn.) Loeske ex O. Maort. [syn. S. gracile (Schleich. ex Roehl.) Limpr.] - Qt, $\mathrm{Uj}$.

*S. SUBCONFERTUM (Broth.) Deguchi - H, Zhao 93200, new to the province. Although the specimen is sterile, the widely ovate leaves with broadly acute apices with or without a short hairpoint fit nicely the illustration of this species in Deguchi (1978) and the herbarium specimens so named at $\mathrm{FH}$.

*S. TRICHODON (Brid.) Poelt - H, Uj, Tan 931290. Here we follow Cao \& Vitt (1986) in accepting this as a distinct species apart from the $S$. strictum complex. The other reported Chinese locality of this Laurasian species is from Taiwan.

Sematophyllum SubHumile (C. Muell.) Fleisch. [Zhao 1993a]

SPHAGNUM ACUTIFOLIOIDES Warnst. [Zhao 1990]

S. CAPILlifolium (Ehrh.) Hedw. [syn. S. nemoreum Scop., S. acutifolium Ehrh. ex Schrad., $S$. capillaceum (Weiss) Schrank.] - K. The choice of this name over the apparently older $S$. nemoreum Scop. is well justified by Crum (1984). As stated, $S$. nemoreum is an uncertain name with no unequivocal, original material available for a typification and definition. S. capillifolium is the most common species of peatmoss encountered in Kanash Nature Preserve.

*S. RUBELlUM Wils. [syn. S. capillifolium var. tenellum (Schimp.) Crum, S. capillaceum var. tenellum (Schimp.) Andrews] - K, Tan 93-923, 93-925. This is the second common species in the minerotrophic bog by Kanash Lake. Whereas S. rubellum is difficult to separate from $S$. capillifolium in many places and has been so treated as a variety of the latter, the two taxa, nevertheless, appear to be distinctive in the study area and can be identified by the morphology of their stem leaf and their overall physical appearance (see Nyholm 1954-1969; Andrus 1980).

*S. SQUARROSUM Crome in Hoppe - K, Tan 93913. This species is easily recognized by its large size, bright green color and squarrose branch leaves. The specimen was collected from a wet trunk base inside Picea forest far from the lakeshore.

*S. TERES (Schimp.) Aongstr. - K, Tan 93-920. This is another minerotrophic, hummock-forming peatmoss found in open lakeshore. The species has the appearance of a slender S. girgensohnii Russ. or a large, green $S$. capillifolium. From the former, $S$. teres can be separated by the absence of an erose- laciniate stem leaf apex and the leaf chlorophyllose cells largely exposed towards the convex side in cross section. From $S$. capillifolium, it differs in having a large terminal bud in its capitulum and, again, in the leaf chlorophyllose cells largely exposed on the convex side in cross section. Stem leaves of $S$. teres also have broadly rounded and fringed apices.

***S. WARNSTORFII Russ. $-\mathrm{K}$, Tan 93-921. The addition of this circumpolar species to the Chinese Sphagnum flora is to be welcome. With its pinkish to reddish pigmentation and slender appearance, $S$. warnstorfii can be mistaken for $S$. rubellum or $S$. capillifolium in Kanash Lake area. However, microscopically, the markedly five row arrangement of branch leaves and the broadly rounded and fringed apex of stem leaf will help establish the identity of $S$. warnstorfii.

Stegonia Latifolia (Schwaegr. in Schultes) Vent. ex Broth. - Qh, Ug.

**TAYlORIA ACUMINATA Hornsch. - Qt, Up, Tan 93-868, 93-989, new generic and species records. Additional Chinese records came from Xizang and, doubtfully, the coastal Shandong Province (Z.-T. Zhao \& al. 1991). We suspect that the Shandong report is based on a misidentified specimen of $T$. serrata, a species with similar leaf morphology.

**Tetraphis Pellucida Hedw. [syn. Georgia pellucida (Hedw.) Rabenh.] - K, Tan 93-1117, new generic and species records. The finding of this widespread boreal moss in Xinjiang was long overdue.

*Tetraplodon angustatus (Hedw.) Bruch et Schimp. in B.S.G. - K, Tan 93-903, a new species record. Its reported range which includes Heilongjiang, Jilin, Inner Mongolia, Xinjiang, Sichuan and Yunnan Provinces, indicates its likely presence in the adjacent provinces of Xizang and Qinghai.

T. URCEOlatus (Hedw.) Bruch et Schimp. in B.S.G. [de la Varde 1937]

Thuidium CYMBifolium (Dozy et Molk.) Dozy et Molk. [Zhao 1993a et b]

T. PHILIBERTII Limpr. [syn. T. delicatulum var. radicans (Kindb.) Crum et al.] - T, Uh, Up.

T. PYCNOThallus (C. Muell.) Par. [Zhao 1993a, b]

TIMMIA AUSTRIACA Hedw. [Zhao 1991]

T. BAVARICA Hessl. - H.

T. MEGAPOLITANA Hedw. [syn. T. shensiana C. Muell.] [Zhao 1991]

T. NORVEGICA Zett. [Zhao 1991]

TOMENTYPNUM NITENS (Hedw.) Loeske - K. TORTELlA FRAGILIS (Hook. et Wils.) Limpr. Qt.

***T. NITIDA (Lindb.) Broth. - Qh, Tan 93-1087, new to China. This species is easily recognized by its strongly crisped leaves when dry, with numerous broken leaf apices. In leaf areolation, it is very much like T. tortuosa. Crum \& Anderson (1981) regarded 
it as T. tortuosa var. nitida (Lindb.) Pilous. Tortella nitida has a sporadic range across Western and Central Europe, Central Asia, North America, and reaching N. Africa.

T. TORTUOSA (Hedw.) Limpr. - Ug.

TORTUla CANINERVIS (Mitt.) Broth. [syns. Grimmia cucullata Lou et Wu; Tortula desertorum Broth.] - H, Qt, S.

T. LONGIMUCRONATA Li [Zhao 1992]

T. MUCRONIFOLIA Schwaegr. [syn. Syntrichia mucronifolia (Schwaegr.) Brid.] - H, Qh, Qt, Uh, $\mathrm{Up}$.

T. MURALIS Hedw. [Anonymous 1985]

*T. PAGORUM (Milde) De Not. - Qh, Tan 93882 , new to the province. This species is easily recognized by the presence of a cluster of papillose, ecostate, leaflet-like gemmae at the stem apex surrounded by a rosette of mostly shortly obovate with rounded to retuse, but awned, apices. In spite of its broad range in semi-arid and arid regions in the world, the first Chinese record was reported only a year ago by Bai \& Gao (1993) from Inner Mongolia. In Xinjiang, only female plants were seen from an arid hillside location outside the Qinghe town. For a clear species definition, Stone's (1971) discussion and illustrations should be consulted.

T. PRINCEPS De Not. [syn. Syntrichia princeps (De Not.) Mitt.] [Zhao 1993a]

T. REFLEXA Li [Zhao 1993b]

T. SCHMIDII (C. Muell.) Broth. [Zhao 1993a]

T. SINENSIS (C. Muell.) Broth. in Levier [syn. Syntrichia alpina (Bruch et Schimp. in B.S.G.) Jur.; $T$. alpina (Bruch et Schimp. in B.S.G.) Bruch in Breut.] - S, Un.

T. SUBUlata Hedw. [Zhao 1993a]

TRACHYCYSTIS MICROPHYLLA (Dozy et Molk.) Lindb. [X.-J. Li et Zhang 1979]

T. USSURIENSIS (Maack et Regel in Regel) T. Kop. $-\mathrm{T}$.

**Trematodon ambiguUs (Hedw.) Hornsch. Ug, Tan 93-962, new generic and species records. This is an uncommon species in China. Previous records are from Heilongjian, Jilin and Yunnan. The Xinjiang population grows on dung piles by a rocky road bank.

VOITIA NIVALIS Hornsch. [Zhao 1993b]

**WARNSTORFIA EXANNULATA (Schimp. in B.S.G.) Loeske [syn. Drepanocladus exannulatus (Schimp. in B.S.G.) Warnst.] [Anonymous 1978]

WEISSIA CONTROVERSA Hedw. - H, S.

\section{Excluded and Doubtful Records}

Anacamptodon latidens (Besch.) Broth. - Zhao (1993a) reported this growing on rock on Mt. Bogda in Tianshan. The specimen cited (Zhao 2502) is Amblystegium serpens. Species of Anacamptodon usual- ly grow on knotholes and fissures of tree trunks. Without capsules, specimens can be difficult to separate from Amblystegium serpens.

Calliergidium bakeri (Ren.) Grout - Lou \& Zhao (1991) reported this species from the Picea forest in Ba-li-kun County, Xinjiang, as another example of the well known floristic affinity between China and Eastern North America. The specimen cited (Zhang 1377), however, is Hygrohypnum luridum, a widespread Holarctic species. Calliergidium bakeri remains an Eastern North American endemic.

Fissidens grandifrons Brid. - The report of this species in Zhao (1993a) is based on a misidentified specimen of $F$. perdecurrens. Considering its total range in the northern hemisphere, $F$. grandifrons is likely to be present in Xinjiang.

Giraldiella levieri C. Muell. - The report in Zhao (1993a, 1993b) is a misidentified Pylaisiella falcata.

Haplohymenium longinerve (Broth.) Broth. - The report of this species from Kanash Lake in Zhao et al. (1989) proves to be a Lescuraea incurvata.

Orthomnion handelii (Broth.) T. Kop. - Specimen cited in Zhao (1993a, 1993b) is a Mnium stellare. The genus Orthomnion has a temperate to subtropical range and is unlikely to be present in Xinjiang area.

Plagiomnium affine (Funck) T. Kop. [syn. Mnium affine Bland. ex Funck] - Gao (1977) mentioned Xinjiang for the distribution of this species in China. Koponen (1981) stated that this is strictly an European taxon. Its presence in China needs confirmation.

P. venustum (Mitt.) T. Kop. - Zhang (1978) reported this for Xinjiang. However, other Chinese records of this species had been rejected by Koponen (1981) who stated that $P$. venustum is a North American Pacific Coast endemic.

Pogonatum aloides (Hedw.) P. Beauv. - Specimen of this species reported in Zhao (1993a) needs re-examination. Hyvoenen (1989) stated that most reports of this species from Asia and continental Africa are erroneous.

\section{Acknowledgements}

We are grateful to the National Geographic Society for the funding support to conduct field works in Xinjiang Province of China. The field companionship and assistance provided by Dr. A. Whittemore (MO), Profs. Zhu Rui-Liang and Mamtimim Sulayman, and the two drivers, Messrs. Wang Min and Amusala, are deeply appreciated. The cooperation and support of the University Administration and Biology Department of East China University in Shanghai and the Xinjiang University in Urumqi are equally acknowledged. Drs. H. Ando, W. Buck, J. Lewinksy, X.-J. Li and Z. Iwatsuki kindly determined some diffi- 
cult specimens. Mrs. C. Hesterberg improved the English text. Lastly, Dr. M. Ignatov kindly checked the correct authority of binomials used in the check- list and provided critical comments on the species distributions in Russian Altai Region for comparison.

\section{Literature Cited}

[ABRAMOVA, A. L. \& I. I. ABRAMOV] АБРАMOBA, А. Л. \& И. И. АБРАМОВ 1983. Конспект флоры мхов Монгольской народной республики. - [Conspectus of the bryophyte flora of the Mongolian People's Republic]. Биол. Ресурсы и Природные Условия Монгольской народной республики [Biol. Resursy i Prirodnye Usloviya Mongolskoi Narodnoi Respubliki] 17: 1-222.

[ABRAMOVA, A. L. \& TS. TSAEGMAED] АБРАMOBA, А. Л. \& Ц. ЦЭГМЭД 1989. К бриофлоре Монгольского Алтая. - [On the bryoflora of Mongolian Altai]. Новости Cист. Низш. Pacm. [Novosti Sist. Nizsh. Rast.] 26: 136-146.

ANDO, H. 1978. Pylaisiella falcata (B.S.G.) Ando, a moss of East Asia-Latin American distribution. - Phyta 1: 14-23.

ANDRUS, R. E. 1980. Sphagnaceae (peat moss family) of New York State. - New York State Museum Bull. 442: $1-89$.

ANONYMOUS 1978. Vegetation of Xinjiang and Its Utilization. - In: Report of Integrated Multidisciplinary Xinjiang Expeditions. Beijing, Institute of Botany, Academia Sinica.

ANONYMOUS 1985. Biota of Mt. Tuermu area of Tianshan Range, pp. 177-181. - In: Report of Academia Sinica Moutain Climbing and Scientific Expedition. Urumqi, Xinjiang People Press.

BAI, X.-L. 1987. Preliminary report of mosses in Inner Mongolia, China. - Acta Scientiarum Naturalium Univ. Intramongolicae 18: 311-350.

BAI, X.-L. \& C. GAO 1993. Newly recorded genus and species of Pottiaceae in China. - Acta Scientiarum Naturalium Univ. Intramongolicae 24: 421-426.

CAO, T., C. GAO \& J.-C. ZHAO 1992. Studies of Chinese bryophytes (3). Revision of Grimmia chenii Lin (Bryopsida, Grimmiaceae). - J. Hattori Bot. Lab. 71: 69-73.

CAO, T. \& D. H. VITT 1986. A taxonomic revision and phylogenetic analysis of Grimmia and Schistidium (Bryopsida: Grimmiaceae) in China. - J. Hattori Bot. Lab. 61: 123-247.

CHEN, P.-C. (ed.) 1963. Genera Muscorum Sinicorum. Pars prima. Beijing, Science Press, 304.

CHEN, P. C. (ed.) 1978. Genera Muscorum Sinicorum. Pars secunda. Beijing, Science Press, 331.

CHEN, P. C. \& AL. 1958. Preliminary report of the cenological and geographical study of Chinese moss flora. - Acta Phytotax. Sinica 7: 271-293.

CRUM, H. A. 1984. Sphagnosida, Sphagnaceae. - North America Flora ser. II, Part 2: 1-180.

CRUM, H. A. \& L. E. ANDERSON 1981. Mosses of Eastern North America. 2 vols. - New York, Columbia University Press, 1328.
DEGUCHI, H. 1978. A revision of the genera Grimmia, Schistidium and Coscinodon (Musci) of Japan. - J. Sci. Hiroshima Univ., ser. B, Div. 2 (Bot.) 16: 121-256.

GAO, C. (ed.) 1977. Flora Muscorum Chinae BorealiOrientalis. Beijing, Science Press, 404.

De La VARDE, P. 1937. Contribution a la flore bryologique de la Chine. - Rev. Bryol. Lichŭnol. 10: 136-145.

HONG, R.-L. \& R.-L. HU 1984. A study on mosses of Mt. Jiulong in Zhejiang Province. - Res. Forest Ecosyst. 4: 207-241.

HYVOenen, J. 1989. A synopsis of genus Pogonatum (Polytrichaceae, Musci). - Acta Bot. Fennica 138: 187.

IGNATOV, M. S. \& O. M. AFONINA (eds.) 1992. Checklist of mosses of the former USSR. - Arctoa 1: 1-85.

IRELAND, R. R. 1968. Pleuroziopsidaceae, a new family of mosses. - J. Hattori Bot. Lab. 31: 59-64.

KOPONEN, T. 1981. A synopsis of Mniaceae (Bryophyta). VI. Southeast Asian taxa. - Acta Bot. Fennica 117: 134 .

KOPONEN, T. \& O. AFONINA 1992. Miscellaneous notes on Mniaceae (Bryophyta). XV. Genus Rhizomnium in the Russia east of Ural Mts. - Bryobrothera 1: 245-250.

KOPONEN, T. \& J.-S. LOU 1982. Miscellaneous notes on Mniaceae (Bryophyta). XII. Revision of specimens in the Institute of Botany, Academia Sinica, Beijing, China. - Ann. Bot. Fennici 19: 67-72.

LAWTON, E. 1971. Moss Flora of the Pacific Northwest. - Nichinan, Hattori Botanical Laboratory, 362+195 pl.

LEWINSKY, J. 1974. The genera Leskeella and Pseudoleskeella in Greenland. - Bryologist 77: 601611.

LEWINSKY-HAAPASARRI, J. \& B. C. TAN 1994. Orthotrichum hallii Sull. et Lesq. new to Asia. - Harvard Papers Bot.: submitted.

LI, X.-J. \& M. ZHANG 1979. Studies on the Chinese Mniaceae. - Acta Bot. Yunnanica 1: 32-80.

LI, Z.-H. 1992. Distribution and bryofloristic elements of Fissidens (Fissidentaceae, Musci) in China. - Bryobrothera 1: 83-91.

LOU, J.-X. \& J.-C. ZHAO 1991. New record of Calliergidium (moss) in China. - J. Xinjiang Univ. 8: 70-71.

McINTOSH, T. 1989. Bryophyte records from the semiarid steppe of Northwestern North America, including four species new to North America. - Bryologist 92: 356-362.

NYHOLM, E. 1954-1969. Illustrated Moss Flora of Fennoscandia II. Musci. Fasc. 1-6. - Lund and Stockholm.

QIAN, L. 1987. A study of Chinese Brachytheciaceae. - M. 
Sc. Thesis. East China Normal University, Shanghai.

REDFEARN, JR., P. L. 1993. List of mosses of China (Tropicos data base). - Springfield, Ozarks Regional Herbarium, Southwest Missouri State University.

STEERE, W. C. 1975. The occurrence of Pseudoleskeella papillosa in Canada and Arctic Alaska. - Lindbergia 3: 91-92.

STONE, I. G. 1971. The sporophyte of Tortula pagorum (Milde) De Not. - Trans. Brit. Bryol. Soc. 6: 270-277.

TCHEN, P.-TC. 1936. Note preliminaire sur les bryophytes de Chine. - Contr. Inst. Bot. Natn. Acad. Peiping 4: 301-336.

VITT, D. H. 1972. A monograph of the genus Drummondia. - Can. J. Bot. 50: 1191-1208.

WILSON, P. \& D. H. NORRIS 1989. Pseudoleskeella in North America and Europe. - Bryologist 92: 387-396.

ZHANG, M.-X. 1978. Flora Tsilingensis. III, Bryophyta (pars 1). - Beijing, Science Press [in Chinese].

ZHAO, J.-C. 1990. A preliminary study of ground vegetation inside Picea obovata forests. - Xinjiang Forestry Sci. Tech. 1 (April): 22-24 [in Chinese].
ZHAO, J.-C. 1991. A study of the genus Timmia Hedwig inside Picea forest of Tianshan, Xinjiang. - Xinjiang Forestry Sci. Tech. 1 (March): 21-23 [in Chinese].

ZHAO, J.-C. 1992. New records of bryophytes to Xinjiang, China (I). - J. Xinjiang Univ. (Nat. Sci.) 9(4): 79-83.

ZHAO, J.-C. 1993a. Study on the bryophytes on Mt. Bogda, Xinjiang. - J. Xinjiang Univ. (Nat. Sci.) 10(1): 73-92.

ZHAO, J.-C. 1993b. A preliminary study on the bryophytes of eastern section of Tianshan Mountains, Northwest China. - Chenia 1: 99-112.

ZHAO, J.-C. 1993c. Pterygoneurum, a new generic record of Chinese mosses. - In: Proceedings of First Academic Meeting of Young People Sponsored by Xinjiang Assocation of Sciences: 194-195 [in Chinese].

ZHAO, J.-C., X.-M. PI \& J.-J. LI 1989. An investigation on the bryophytes of Kanasi Natural Reserve. - $J$. Xinjiang Univ. (Nat. Sci.) 6(4): 78-83.

ZHAO, Z.-T., S.-J. FAN, F.-Z. LI \& Y.-C. CHIN 1991. A Study on the utilization and development of bryophyte resources in Shandong Province. - Department of Biology of Shandong Normal University [in Chinese]. 